\title{
Primary Exploration into "1 + 3" Integrated Teaching Method
}

\author{
Zhimin Lei $^{1, \text { a, * }}$, Jiayan Zhang ${ }^{\text {2, b }}$, and Qiao Mou ${ }^{3, \mathrm{c}}$ \\ ${ }^{1}$ College of Marxism, Sichuan Agricultural University, Chengdu 611130, China \\ ${ }^{2}$ College of Marxism, Sichuan Agricultural University, Ya’an 625014, China \\ ${ }^{3}$ College of Marxism, Sichuan Agricultural University, Ya’an 625014, China \\ a1007930161@qq.com, b546270641@qq.com,'790534495@qq.com
}

Correspondence: Zhimin Lei

Keywords: Ideological and political education in universities, Morality education, "1 +3" integrated, Teaching experiment, Teaching methods

\begin{abstract}
The real value of Chinese colleges and universities exists in "morality education", the main channel of which is ideological and political course. The key to morality education lies in how to effectively integrate students into ideological and political education. The " $1+3$ " integrated teaching method takes major political education or commemorative activities in "1" period as an educational opportunity, relies on case-based, project-based, participatory teaching means and methods to construct "3" integration platform with interconnection and interaction between curricular and extracurricular, online and offline education that dynamically integrates students' learning outcomes, history education activities of mainstream media, and campus cultural construction activities into theory study.
\end{abstract}

\section{State of the literature}

-Although there are differences between European and American systems and values, they all attach great importance to the study of how to take high moral values establishment and people cultivation.

-Europe and the United States attach importance to students' subjective behavior and integrate effectively into the whole process of education, which is not only the weak link of Chinese universities' thinking and government education, but also the focus of the study on education.

-Using foreign experience to explore new method of ideological and political teaching.

\section{Contribution of this paper to the literature}

- The West attaches importance to students' subjective participation, and China emphasizes the combination of value cultivation and policy education.

- A new teaching model characterized by the construction of major problem-oriented and students ' active integration into multi-platform learning.

-Students' subjectivity, teaching openness and practicality are the new ways of "knowing and doing in unity".

\section{Proposal of " $1+3 "$ integrated teaching method}

The subject of ideological and political education is teacher and also student, but effectiveness of ideological and political education ultimately depends on whether students are physically and mentally integrated into educational activities. The idea of "1 +3 " teaching method meets what General Secretary Xi Jinping emphasizes in recent years: "We should improve affinity and pertinence of ideological and political education to meet needs and expectations of students' growth and development"[11] (Xi, 2016). Specifically, there are four factors below.

First, considering the unique political guidance and timeliness of ideological and political education, we must grasp the education opportunities. The primary task of ideological and political course is to foster ideal and faith as well as core values of socialism, and to carry out the theory education of socialism with Chinese characteristics through various channels. Since the 18th CPC 
National Congress, spirits of a series of important speeches by General Secretary Xi Jinping have become a part of ideological and political education contents. Thus, CCP and the state require ideological and political education should "carry out theme education with the great achievements of our country in reform and development, commemorative activities of major historic events, patriotic education base and national sacrificial rituals [13]." (The State Council of the CPC Central Committee, 2017). Therefore, make use of commemorative activities in "1" period as education opportunities to design teaching programs and "plans" to improve teaching and enrich course materials. so that ideological and political education can follow the trend of the times and fit the new situation.

Second, "ideological and political course is about method [1]" (Chen, 2017). Teachers of ideological and political theory course shoulders the responsibility of "disseminators of advanced ideology and culture, staunch supporters of ruling party, guiders and mentors of students' healthy growth [11]" (Xi, 2016). However, as stated by minister of education Chen Baosheng, our "ideological resources are abundant, practice cases are rich, what we lack is appropriate method." In a certain sense, ideological and political course is about method. We should employ methods suited to students' characteristics and needs to vividly present CCP's rich ideological resources and fresh practice cases to students [1]" (Chen, 2017). Faced with the changes in cognitive characteristics and requirements of contemporary college students and further promotion of the Internet revolution, it has become an urgent need in ideological and political reform to timely optimize and innovate teaching methods proactively.

Third, teaching methods must be suitable for contemporary college students' thinking mode and development needs. "Success in higher education means that students exit with not only critical knowledge and skills but also habits of mind that support professional success and lifelong learning [2]" (Alexander, 2017). Today's students have some ability to distinguish between right and wrong, but they have some incorrect understanding of considerable historical and practical issues under the influence of diversified thoughts and network. Students have some understanding of basic theory of Marxism China's historical development and socialism with Chinese characteristics. But many students only know what is do not know why. Some students lack the correct thinking mode and method to analyze problems. Often confused, they are anxious for teachers' guidance to enhance their ability to analyze and solve problems. Thus, how to enhance attractiveness, persuasiveness and infection of ideological and political teaching so as to lay a solid ideological foundation for training reliable successors to the cause of socialism with Chinese characteristics is the motivation to explore " $1+3 "$ teaching method that integrates students into ideological and political education.

Fourth, we should innovate ways of ideological and political education by Internet thinking. "The rise of the internet helped fuel additional changes in the higher education landscape [3]" (Rawn and Fox, 2017). In turn, the rise of Internet has promoted the reform of ideological and political courses in universities. For college students growing up with mobile internet, mobile internet thinking of equality, interaction, openness, participation and sharing gradually permeates their cognition and behavior needs. Such cognition and behavior needs reversely requires that ideological and political education and teaching must advance in the direction of interactive, open teaching reform, explore and adapt to teaching methods delighted to students featuring mutual learning, mutual progress, sharing and joint development, select corresponding teaching tools and platforms integrating online and offline education resources, curricular and extracurricular education activities in one, provide idea guidance in "equal communication, democratic discussions, interactive exchange" for the purpose of targeted, lively work progression [13]" (The State Council of the CPC Central Committee, 2017).

\section{Implementation plan of " $1+3 "$ integrated teaching method}

To integrate students into the education process is the key to success of education. The "1 + 3" integrated teaching method that integrates students into ideological and political education embodies the organic unity of form and content, theory and practice, history and reality. " 1 " means to take major educational practice (memorial) activities of CCP and state in a period as educational 
opportunities; "3" means to establish "three integration" teaching modules in the education process that integrate students' learning outcomes into theory study to make history fresh and real. The premise of implementing " $1+3$ " integrated teaching method lies in "understanding the three conditions to have a definite objective". First, we should understand learning condition before "soliciting questions". Second, we should understand political condition, pay close attention to the hot issues of ideological and political education. Third, we should understand the teaching condition. Teachers should determine and carry out research on teaching topics to create education condition.

The main content of implementing "1 + 3" integrated teaching method lies in skillfully seizing education opportunity "1" and focusing on building "3" integrated teaching modules.

Skillfully seize the education opportunity "1". "Creativity supports the advancement of all disciplines, providing both individual and societal benefits [4]" (Lisa DaVia Rubenstein et al., 2017). Guided by the spirit of General Secretary Xi Jinping's series of important speeches since 2012, with major education practice (commemorative) activities in "1" period, implementation of "1 +3 " integrated teaching method is to develop teaching plans, plan teaching programs and perform teaching activities around the course focus according to teaching objectives and student situations.

Focus on building "3" integrated teaching modules. "All disciplinary learning is situated in the social contexts in which students and teachers find themselves [5,9]" (Harland and Wald, 2018). In the process of teaching implementation, according to the specific teaching condition, we timely combine teaching methods and means, such as "case-based teaching, project-based independent learning and participatory reading", and gradually build the "three integration" teaching modules that integrate students' learning outcomes into theory study. Guiding students to use Marxism's basic positions, perspectives and methods in correct analysis, correctly understand major historical, practical and theoretical issues and form correct thinking mode and value through integrated learning, thus truly enhancing effectiveness of ideological and political education.

\subsection{Module 1, "interactive" flipped classroom of "I investigate" + "I attend the class"}

Feature: Students' learning outcomes are integrated into theory study

The module consists of a "1 + 4" mechanism. "1" means to grasp the educational opportunity. Year 2016 marked the 80th anniversary of the victory Long March of Chinese Workers and Peasants' Red Army. the entire nation set off learning and practice activities to commemorate the Long March, Taking this great opportunity of ideological and political education, we center around the teaching focus of "the motivation, history and experience of the Chinese Communist Party in pioneering a new road to the Chinese revolution", Then developing the hybrid teaching programs based on field trips + online learning + classroom interactive teaching, case-based + participatory + project-based teaching methods. "4": 4 processes reflected in: 1) problem-orientation. Centering on how to understand reason, measures and important role of Chinese "land revolution"; how to "carry forward the spirit of the Long March and take the new path of Long March well", teachers instruct the students to read the relevant contents online. 2) Group collaborative learning. Students are required to study and discuss in learning groups and form discussion draft. Activities are incorporated into ordinary review. 3) Combination of student representatives' on-the-spot investigation and all students' online virtual inspection., we organize student representatives to conduct investigation in Qionglai Red Army Memorial Hall, collect relevant historical data to make teaching cases and scripts. At the same time, we organize all students to visit Red Army Long March Memorial Hall online with questions, collect relevant materials and prepare for class presentation. 4) "Embedded" classroom teaching shared by teachers and students. Based on the micro-topics of "friendly harmony between military and civilian" and "fighting against local tyrant and distributing land among people", students in the field visit walk on the podium. Student on the podium displays, Field visit students pour out words and have interactions with the student on the podium. Teacher makes timely comments, forming strong classroom atmosphere with teacher-student, student-student education and self-education. 


\subsection{Module II, "interactive" teaching platform featuring "party media activities + classroom teaching + extracurricular activities"}

Feature: history education activities of mainstream media is integrated into theory study

"Social Networking Sites (SNSs) have become a mainstay in the lives of many adolescents and adults worldwide [6]" (Marker et al., 2017). First, establish "1", that is, grasp the educational opportunity. Year 2015 marked the 70th anniversary of the victory of the Chinese Anti-Japanese War and the World Anti-Fascist War. Guided by the important speech made by General Secretary $\mathrm{Xi}$ Jinping during the commemoration of the 70th anniversary of the victory of the Chinese Anti-Japanese War and the World Anti-Fascist War, we take the commemoration as opportunities to develop teaching plans that integrate history education activities of mainstream media into theory study, instruct students to log onto mainstream media websites to participate in the colorful historical education and thematic practice activities.

Second, implement the "3 steps" measures to build three interactive platforms. The first step is "scale" learning. According to interests of students, we organize nearly 1,000 students to participate in prize-giving promotion competition sponsored by Qiushi Network, The results of the competition in the form of WeChat swing are incorporated into ordinary review in category of students' extracurricular activities [12]. The second step is "point" study. Guided by the spirit of speech made by General Secretary Xi Jinping in commemoration of the 70th anniversary of the victory of the Chinese Anti-Japanese War and the World Anti-Fascist War, we combine textbook contents to propose 10 research topics consistent with the research direction. Then, make students form teams, select topics, make proposal, have group discussions, compose drafts and form research results. The third step is "theory" preaching. Group members report the research results in class or join the teacher's lecture "Anti-Japanese War of Chinese Nation" in time according to the teaching progress. By combining online and offline education resources, project-based learning and classroom learning, adheres to the teaching idea of "unity of knowing and doing", thus becoming an effective way welcomed by students to enhance their ideological and political theory and comprehensive quality.

\subsection{Module III, “interactive" teaching platform featuring "entry into the campus +walking onto the podium"}

Feature: Campus cultural construction activities are integrated into theory study

Taking the example of centennial activities of Sichuan Agricultural University, making use of school-based resources and inter-provincial resources to strengthen history education is an effective way to enhance effectiveness of ideological and political education.

The module consists of "1321" pearl chains:

"1": grasp the educational opportunity. "Outline of Chinese Modern History" course group takes the 110th anniversary of founding of Sichuan Agricultural University as an educational opportunity to launch interview activities of "Sichuan Agricultural University's stories and Chinese Dream Behind"-"Oral History - Sichuan Agricultural University People' Dream-chasing Years". "3": 1) Set up a management team. A learning committee is established based on teacher team -subject representative- study secretary- group leader to guide the establishment of research teams consisting three to six people, develop activity programs and proceed with pre-publicity and preparation. 2) Smoothen management channels. Questions are answered through QQ group, public mail media to promote the process of activities. 3) Hold a training session. Teachers give training of main purpose, principle, topic selection requirements, network resources, methods and evaluation process of the activity among subject representatives, study secretary, group leaders. Then, the training materials and related learning materials are uploaded to the special public mailbox of the course for students to learn. "2": 1) Provide reference for topic selection, give guidance to activities. With topic selection from "New Deal" in the late Qing Dynasty and the creation of Sichuan Agricultural University, Sichuan Agricultural University teachers and students' contribution to Anti-Japanese War, cause and effect of relocation of Agricultural College in 1956, building of Sichuan Agricultural University as 211 project university, etc. teachers instruct students to combine resources tapped online with on-site interviews. 2) Design "class self-evaluation + grade 
assessment" mechanism. The entire appraisal process upholds the principle of openness, justness and fairness. Winning group will be selected according to detailed grading rule and proportion. Next, commendation meeting will be organized to attract more students' attention and participation.

Nearly 1,400 students participated in the series interviews. As a result, history walks out of books and gain life [8]; students feel history through individual experience, then the grand themes are replaced by struggle facts one after another. Students' educational practice enriches history education, enriches campus culture, and also enhances students' sense of teamwork, awareness of assistance with their copywriting and interpersonal communication skills strengthened. Students quite accept "interactive" teaching platform featuring "entry into the campus + walking onto the podium".

\section{Conclusion}

In the process of exploring the " $1+3 "$ integrated teaching method that integrates students into ideological and political education, we follow the rule of imparting knowledge and educating people, construct a teaching community where teachers and students interact with others and learn from each other according to the principle that teaching benefits teachers as well as students and practice and knowledge are the unity of learning, seize major educational opportunities by leveraging time, place and occasion, build the "interactive" flipped classroom featuring "I investigate" + "I attend the class" that integrates learning results of teachers and students into theory study; build "interactive" teaching platform featuring "party media activities + classroom teaching + extracurricular activities" that integrates history education activities of mainstream media into theory study;

In general, change and development of things cannot be separated from a certain carrier. The "1 $+3 "$ integrated teaching method that integrates students into ideological and political education has become an effective carrier to "improve affinity and pertinence of ideological and political education and meet the needs and expectations of students' growth and development." Students' integration is the key to effectiveness of ideological and political education. This integration should not only be a formal integration, but, more importantly, "integration of heart". " $1+3$ " integrated teaching method win students' recognition to ideological and political course teaching and education. Catered to students' cognitive habits under the era of mobile Internet, it finds the best combination point that not only meets students' cognitive habits, but also "meets the needs and expectations of students' growth and development". Although this teaching method still needs to be further perfected, it has wider promotion and reference significance due to scientificity of its reform ideas and operability of specific measures.

\section{Acknowledgement}

This article is phased achievement of the 2015-2016 general project of "Research on Sichuan University Students' Marxism Faith Education" of Sichuan Province Higher Education Research Institute of Ideological and Political Education (scsz201538) and the general project of "Marxism Faith Education Research" of Federation of Humanities and Social Sciences of Sichuan Agricultural University (2013YB03).

\section{References}

Reference to journal papers

[1] Chen B.S. Keep in mind General Secretary Xi Jinping's entrustment, do a good job in ideological and political course education in colleges and universities[J]. China Higher Education, 2017-06-05.

[2] Alexander, P.A. (2017). Issues of Constructs, Contexts, and Continuity: Commentary on Learning in Higher Education [J]. Educational Psychology Review, 29(2), 345-351. 
[3] Rawn, CD \& Fox, J.A. (2017). Understanding the Work and Perceptions of Teaching Focused Faculty in a Changing Academic Landscape[J]. Research High Education, https://doi.org/10.1007/s11162-017-9479-6

[4] Lisa DaVia Rubenstein, Gregory L. Callan, Lisa M. Ridgley. (2017). Anchoring the Creative Process Within a Self-Regulated Learning Framework: Inspiring Assessment Methods and Future Research [J]. Educational Psychology Review, https://doi.org/10.1007/s10648-017-9431-5

[5] Harland, T. (2017). Bruce Macfarlane: Freedom to learn: the threat to student academic freedom and why it needs to be reclaimed[J]. High Education, 74(6), 1109-1112.

[6] Marker, C., Gnambs, T. \& Appel, M. (2017). Active on Facebook and Failing at School? Meta-Analytic Findings on the Relationship Between Online Social Networking Activities and Academic Achievement[J]. Psychology Review, https://doi.org/10.1007/s10648-017-9430-6

[7] Richardson, J.T.E. (2017). Student Learning in Higher Education: a Commentary[J]. Educational Psychology Review, 29(2), 353-362.

[8] Zhang J.X. Let history go out of textbooks to move students with facts - Sichuan Agricultural University actively explores teaching reform in ideological and political course[J]. Education Herald, 2017-01-05

[9] Harland, T. \& Wald, N. (2018). Curriculum, teaching and powerful knowledge[J]. High Education, https://doi.org/10.1007/s10734-017-0228-8

Reference to a book

[10]"Higher Education", Personnel Department, Ministry of Education[M]. Beijing: Higher Education Press, 2005, 277.

Reference to conference papers

[11] Xi J.P. (2016). Run ideological and political work throughout the whole process of education and teaching. National conference on ideological and political work in colleges and universities, Beijing, Information on http://www.xinhuanet.com//politics/2016-12/08/c_1120082577.htm

[12] Lei Z.M. Sichuan Agricultural University participated in anti-Japanese war knowledge contest. Original Channel of QiuShi Network, Information on http://www.qstheory.cn/laigao/2015-12/28/m_1117601346.htm

[13] The State Council of the CPC Central Committee. "Opinions on Strengthening and Improving the Ideological and Political Work of Colleges and Universities in the New Situation" issued by the State Council of the CPC Central Committee. Xinhua News Agency, Information on http://www.gov.cn/xinwen/2017-02/27/content_5182502.htm

Associate professor, College of Marxism, Sichuan Agricultural University, Chengdu 611130, China. Address to No.211 Huimin Rd., Wenjiang Dist., Chengdu 611130, China.

Tel:+86 13981616283. 